\title{
Para além de escravos e senhores: sociedade e economia paulistas entre 1750 e 1850
}

$\mathrm{F}$ RANCISCO Vidal Luna e Herbert Klein são estudiosos da história econômica brasileira e americana e, em conjunto, escreveram vários artigos sobre a sociedade e a estrutura da posse de cativos em diversas localidades paulistas e mineiras. O primeiro é professor da Faculdade de Economia da USP e seu estudo Minas Gerais: escravos e senhores (1981) é considerado pioneiro dentre os estudos demográficos relativos ao tema da escravidão. Klein, professor da Universidade de Colúmbia dedicado ao estudo da América Latina e dos Estados Unidos, vem estudando há alguns anos o tráfico de escravos, além de escrever estudos comparativos entre as sociedades escravistas americanas do Norte, Sul e Caribe. Ambos publicaram, em 2003, pela Stanford University Press, Slavery and the economy of São Paulo, 1750-1850, agora traduzida pela Edusp com o título Evolução da sociedade e economia escravista de São Paulo, de 1750 a 1850.

A obra apresenta novos dados, fundamentais para as pesquisas relativas ao mundo do trabalho na capitania e depois província de São Paulo, constituindo referência para o estudo da formação histórica da região. Ao mesmo tempo, amplia e dá novo vulto a estudos de história demográfica ligados aos padrões de posse de cativos em São Paulo, em desenvolvimento desde a publicação, em 1972, do clássico artigo de Alice Canabrava, "Uma economia de decadência: os níveis de riqueza da capitania de São Paulo, 1765-67”.
O texto analisa a estrutura da posse de escravos em várias localidades paulistas, somada e cotejada com outras variantes demográficas, tais como sexo, idade, origem, cor, estado civil e atividades econômicas. As principais fontes consultadas foram os maços de população constantes do acervo do Arquivo do Estado de São Paulo, já utilizados por vários estudiosos, entre eles Maria Luísa Marcílio, que escreveu o primeiro estudo de grande envergadura sobre a demografia paulista colonial. As balizas cronológicas estabelecidas pelos autores foram os anos de 1777, 1804, 1829 e 1836; os três primeiros por coincidirem com os censos populacionais mais completos e o último por fundamentar-se no Ensaio d'um quadro estatístico da Província de São Paulo, de Daniel Pedro Muller, mandado organizar pelo governo provincial e editado pela primeira vez em 1838. Sempre que possível, os autores compararam os dados levantados para São Paulo com os de outras regiões escravistas americanas, tais como Minas Gerais, Bahia, Estados Unidos e ilhas do Caribe, possibilitando ao leitor vislumbrar de forma mais ampla a escravidão nas Américas.

O livro é composto por oito capítulos que podem ser agrupados em três conjuntos: o primeiro capítulo apresenta um histórico da capitania de São Paulo, de suas origens a 1800; entre o segundo e o quarto capítulos foram analisadas, respectivamente, as produções açucareira, cafeeira e de subsistência; 
enquanto os últimos três capítulos são dedicados às características de quatro principais grupos populacionais, quais sejam, o dos proprietários de escravos, o da população escrava, o das pessoas livres de cor e os não empregados no setor agrícola.

Mapeando a configuração econômica de São Paulo, os autores identificam cinco regiões: Capital, Vale do Paraíba, Oeste Paulista, Litoral e Caminho do Sul. A capitania é apresentada como região de fronteira, pobre e atrasada, marcada por culturas de subsistência e por baixos índices populacionais até fins do século XVIII. A única atividade lucrativa anterior ao advento da lavoura açucareira teria sido o comércio de escravos índios, mas o crescimento econômico só se esboçaria depois de 1700 , em razão do abastecimento das minas. Mesmo com a entrada de quantidades significativas de escravos africanos, São Paulo teria conhecido crescimento modesto até 1765 , quando o governo metropolitano implantou políticas de incentivo à produção. A partir de então, desenvolver-se-ia a base de uma economia de mercado centrada na exportação de açúcar.

$\mathrm{O}$ texto ressalta o elevado número de escravos e de índios aldeados (mãode-obra compulsória em potencial) arrolados já no censo promovido em 1765/1766, apontando para a inserção da economia paulista a mercados nacionais e, mesmo internacionais, bem como para o gradual crescimento da economia e da população durante todo o século XVIII. Em 1800, São Paulo finalmente teria se tornado uma economia escravista de "grande lavoura", nos moldes do restante da América portuguesa colonial. Ou seja, seguindo esse encami- nhamento, os autores compartilham das clássicas interpretações de Thereza Petrone, de Alice Canabrava, e de Caio Prado Jr., segundo as quais a ampliação da lavoura canavieira teria aberto uma era de desenvolvimento ao integrar a capitania ao lucrativo comércio de exportação com o Reino europeu.

Evolução da sociedade e economia escravista de São Paulo, entretanto, apresenta dados que permitem alargar esse quadro e subsidiar as novas pesquisas que vêm questionando a visão de São Paulo como região desvinculada da produção mercantil colonial. Estudos produzidos na década de 1990, tais como os de Ilana Blaj e de John Monteiro, lançaram interrogações sobre a imagem da São Paulo colonial desvinculada da economia luso-brasileira, apontando para o uso intensivo da mão-de-obra escrava indígena na produção de gêneros alimentícios para o mercado, bem como para a inserção da capitania nas rotas do comércio interno já no século XVII.

Os dados apresentados por Luna e Klein relativos à ascensão da lavoura canavieira, à introdução do cultivo do café e à permanência e crescimento da produção de gêneros de subsistência durante todo o período estudado vêm ao encontro desses estudos evidenciando sobretudo a crucial importância econômica da lavoura mercantil de abastecimento. Em vez da hipótese historiográfica mais defendida, de que até meados do século XVIII a lavoura açucareira teria se autofinanciado, os autores defendem que os recursos para esse tipo de produção foram gerados pelos produtores paulistas anteriormente ocupados na mineração ou na produção de gêneros para Minas Ge- 
rais e Rio de Janeiro. Diferentemente da maioria dos estudos sobre o tema, que ressaltam o predomínio da grande propriedade monocultora e escravista como marca consagrada da economia e sociedade coloniais, Luna e Klein apontam para a diversidade produtiva das unidades açucareiras paulistas, nas quais se continuou a produzir gêneros de subsistência. A expansão do mercado local teria incentivado esse tipo de produção, além do que os pequenos estabelecimentos agrícolas familiares, produtores de gêneros alimentícios, continuariam em atividade, mesmo quando as unidades açucareiras aumentaram em tamanho, número de escravos e valor da produção.

Conforme argumentam, entre 1804 e 1829 , o número médio de escravos por engenho paulista subiu de dezessete para 31; e ainda em 1829, a média geral de escravos por senhor era de sete cativos. Daí a constatação da concentração de riqueza entre os proprietários dedicados à produção de gêneros de exportação. Em concomitância, os pequenos proprietários e posseiros sem escravos da região açucareira perderam espaço econômico, pois, proporcionalmente, produziam menos valores que seus vizinhos escravistas. Ademais, essas transformações econômicas trouxeram consigo uma série de alterações demográficas relacionadas à ampliação do contingente de escravos africanos, cuja população cresceu três vezes entre 1777 e 1836.

Foi durante a expansão da lavoura canavieira que ocorreu a introdução do cultivo de café no Vale do Paraíba. Inicialmente, a produção de café teria favorecido as unidades produtivas menores, baseadas no trabalho fami- liar ou com poucos escravos, pois, em razão dos baixos custos iniciais e do longo tempo de maturação da planta, seus produtores investiam, também, na lavoura de gêneros alimentícios. As grandes fazendas de café, centralizadas no Oeste Paulista, só seriam uma realidade depois de 1850. Diferentemente dos produtores de açúcar, metade dos produtores de café ainda usava mão-deobra livre em 1829, embora a produção se concentrasse entre os que possuíam escravos.

Nesse sentido, no Vale do Paraíba, o café foi introduzido em fazendas formadas a partir da lavoura mercantil de abastecimento, mas com o passar do tempo a rentabilidade do café proporcionou o ingresso de maior contingente de escravos na região e, embora a produção de milho não tenha sido abandonada nem pelos cafeicultores, a proporção de fazendas dedicadas unicamente ao cultivo de gêneros de subsistência caiu. Mesmo assim, as unidades produtivas familiares, sem ou com poucos cativos, permaneceram importantes na produção de alimentos, e essa, além de ser a base da economia paulista anterior a 1800 , não só manteve sua relevância como se associou à produção para o comércio exterior.

Característico da produção paulista seria o emprego de mão-de-obra escrava junto à mão-de-obra livre familiar na produção de alimentos para o mercado regional. Desse modo, em 1798, em plena "era do açúcar", um terço das exportações paulistas era de gêneros de subsistência, entre eles arroz, feijão, milho e farinha de mandioca, acrescentando-se ainda a criação e comércio de animais. Ou seja, a análise estatística de informações extraídas das fontes le- 
vou os autores a indicar que as regiões açucareiras e cafeeiras em São Paulo, no período em questão, nunca foram "monocultoras". Ainda em 1829, conforme números apontados por Luna e Klein, $75 \%$ dos proprietários de cativos ocupados na agricultura produziam para o abastecimento do mercado interno. Cerca de um quarto desses possuía apenas um escravo, enquanto a grande maioria dos domićlios empregados nessa tarefa não contava com cativos. Contudo, também na produção de alimentos, os proprietários de escravos obtinham maiores níveis de produtividade e lucros, a exemplo da Vila de Cunha, onde as culturas alimentícias tradicionais, nas quais era amplo o emprego de cativos, formavam a base da economia, comprovando o dinamismo desse setor.

Dados como esses possibilitam o questionamento de teses tradicionais acerca da sociedade luso-americana do período, ao ressaltarem o lugar relevante ocupado na economia paulista por pequenos e médios proprietários de escravos, voltados para a produção de gêneros de subsistência.

Segundo os dados apresentados, em 1836, os valores da produção de milho (1.974.277 mil réis) ultrapassaram os obtidos com a venda de café e açúcar (940.858 e 665.647, respectivamente). Também nesse caso, ocorreu uma concentração da produtividade nas mãos dos proprietários de escravos. Os milharais se expandiram junto com as lavouras açucareira e cafeeira, o mesmo ocorrendo com o arroz e o feijão, bem como com a criação de suínos e a fabricação de toucinho. Assim, os autores demonstram que, embora o número relativo de escravos empregados na la- voura de subsistência tenha caído entre 1770 e 1836, a produção de alimentos continuou a se expandir e a se integrar ao sistema escravista, permanecendo como alicerce da economia paulista.

A partir dessas considerações, os autores passam a estudar a população envolvida nessa economia de mercado em expansão, abordando as mudanças demográficas advindas do aumento produtivo. Ressalta-se o extraordinário crescimento populacional no período, da ordem de $2 \%$ ao ano, liderado pelos proprietários responsáveis pelo enorme afluxo de africanos para São Paulo. Nota-se que um terço dos domićlios paulistas, entre fins do século XVIII e início do XIX, possuía escravos; a ampliação da produção para mercado ampliou o número total de cativos na região, mas não o número relativo de senhores dentre a população. Desse modo, cresceu o número de escravos por proprietário, não a proporção desses na população. Entretanto, era a atividade econômica que determinaria o número de escravos possuídos por proprietário, pois a maior parte desses era formada por agricultores, que detinham $75 \%$ da escravaria.

Com o passar do tempo, maior número de escravos se concentrou nas mãos daqueles que produziam para exportação e, conseqüentemente, aumentou também sua participação no total da produção. Embora os pequenos proprietários de escravos fossem ampla maioria, detinham menos escravos: em $1829,75 \%$ dos proprietários possuíam até cinco cativos e detinham $35 \%$ da escravaria. Eram raros os proprietários realmente grandes (com mais de cem escravos), pois a concentração de escravos teria ocorrido entre a camada inter- 
mediária de proprietários, que possuía onze ou pouco mais cativos.

Entre fins do século XVIII e início do XIX, o enriquecimento dos senhores provaria que a sociedade paulista passou a ser cada vez mais definida econômica e socialmente pela escravidão, e o número crescente de escravos integrados à população seria indicativo do dinamismo da economia exportadora. O incremento da população escrava, da ordem de 23 mil para 75 mil entre 1777 e 1829, causou extraordinário aumento no número proporcional de homens adultos, especialmente na região açucareira, prejudicando o crescimento natural dos escravos, mas ampliando sua eficiência econômica com o ingresso de africanos em plena idade produtiva.

Numericamente importante na sociedade paulista também era a chamada "população livre de cor", que constituía um quarto da população total de quase todas as vilas durante o período estudado, mas apenas $6 \%$ do número total dos senhores paulistas. Em sua maioria, eram mulheres, compunham apenas um quinto do setor agrícola, mas eram muito representados entre os artesãos (37\%) e os jornaleiros e pobres (40\%). Estavam plenamente integrados à massa de trabalhadores, aproximando-se da população branca pobre.

$\mathrm{O}$ último setor populacional analisado pelos autores é o chamado "nãoagrícola", bastante heterogêneo com relação às ocupações, posse de cativos e status social. Em 1829, 41\% dos domicílios paulistas não eram agrícolas e detinham $21 \%$ dos escravos. Esses domicílios concentravam-se nas áreas urbanas, especialmente na cidade de São Paulo, em Santos e Paranaguá, e proporcionalmente eram formados por um número maior de pobres e de "não-brancos", a despeito de, segundo os autores, agregarem oficiais militares, altos funcionários do governo, tropeiros e comerciantes, alguns muito ricos e donos de grande escravaria. Dessa categoria fariam parte os artesãos, como costureiras, tecelãs, oleiros, ferreiros, sapateiros, e os agregados. Esses últimos geralmente viviam à sombra de um senhor de escravos, mas, socialmente, estavam acima de jornaleiros, "mendigos" e daqueles que "viviam de sua agência".

Importante ressaltar que, segundo os autores, grande parte dessa população era formada por antigos agricultores, expulsos da terra com a expansão da lavoura de exportação. Aponta-se, assim, para uma situação de expropriação de terras e bens de produção que atingirá a maior parte da população livre e pobre nos finais do século XIX, questão amplamente estudada por Maria Sylvia de Carvalho Franco.

Fundamentada em ampla pesquisa e detalhada análise da documentação, a obra de Francisco Luna e Herbert Klein permite vislumbrar o universo econômico paulista e a multiplicidade de características dos produtores locais em período histórico ainda pouco explorado. Ao atestar a complementaridade entre trabalho escravo e trabalho livre, também permite relativizar as teses historiográficas calcadas no modelo da grande propriedade monocultora escravista como principal forma de ocupação e exploração do território que viria a formar o Brasil. Baseado nesse estudo, é possível afirmar que o significativo desenvolvimento econômico da segunda metade do século XIX e a concentração do número de escravos na produção de açúcar e café em São 


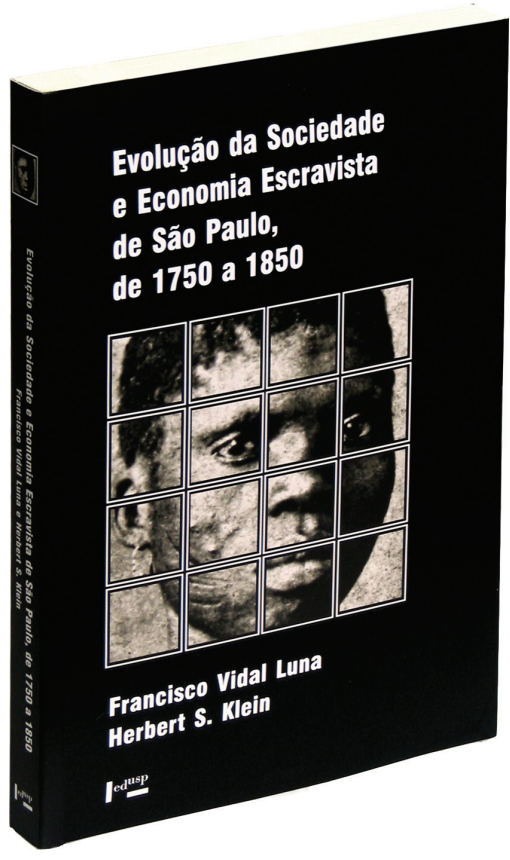

LUNA, F. V.; KLEIN, H. Evolução da sociedade e economia escravista de São Paulo, de 1750 a 1850. Trad. Laura Teixeira Motta.

São Paulo: Edusp, 2006. 280p.

Paulo só foram possíveis graças à preexistência de uma classe de agricultores integrada aos mercados internos, que soube bem usar as vias de transportes e a mão-de-obra local ou africana disponível.

De outro modo, a análise reconstitui um processo de concentração de riqueza, ocorrido tanto no setor agrícola de exportação quanto no de abastecimento, no qual a posse de escravos foi fundamental para a ampliação da participação econômica de pequenos e médios proprietários. A nosso ver, esses segmentos sociais passariam também a atuar, após a Independência, na configuração da ordem liberal e do Império, durante a primeira metade do século XIX, constituindo as bases votantes onde se apoiavam eleitores, deputados provinciais e membros do Parlamento.
Sem dúvida obra obrigatória para estudiosos e pesquisadores da história paulista, Evolução da sociedade e economia escravista de São Paulo apresenta extraordinária quantidade de gráficos e tabelas que contribuem para interrogar e ampliar o entendimento atual acerca de período assinalado por profundas transformações.Lamenta-se apenas que a visualização dos dados tenha sido prejudicada por pequenos erros de diagramação.

Ana Paula Medicci é mestre e doutoranda em História Social pela Universidade de São Paulo. @-apmedicci@gmail.com 